\title{
The Impact of Bail-in Risk on Bank Bondholders
}

\author{
Lorenzo Gai ${ }^{1}$, Federica Ielasi ${ }^{1} \&$ Martina Mainini ${ }^{2}$ \\ ${ }^{1}$ Department of Economics and Management, University of Florence, Italy \\ ${ }^{2}$ Department of Economics and Management, University of Parma, Italy \\ Correspondence: Federica Ielasi, Department of Economics and Management, University of Florence, Italy, Via \\ delle Pandette, 950127 Florence, Italy. E-mail: federica.ielasi@unifi.it
}

Received: May 19, 2020

Accepted: July 30, 2020

Online Published: August 16, 2020

doi:10.5539/ijbm.v15n9p105

URL: https://doi.org/10.5539/ijbm.v15n9p105

\begin{abstract}
The paper investigates the impact of the bail-in regulation on bank bond secondary markets. Using data on outstanding bonds issued by significant Euro-Area banks, the study carries out pooled panel regression analyses to determine the association between yields of "bailinable" and "bailinable" bonds. The paper also analyses the impact of the bail-in tool in relation to bank leverage, which affects the potential severity of losses for bondholders in the case of bail-in. With a sample of 4,855 bonds issued by 45 banks from January 2006 to December 2016, we find an increase in the risk premium for unsecured bonds, and senior unsecured bonds show the greatest effect on yields and yield spread when bail-in regulation came into force. Moreover, a "bail-in severity" premium, related to bank leverage, is identified.
\end{abstract}

Keywords: bail-in, bank leverage, banks, bonds, financial markets, yield spread.

\section{Introduction}

During the financial and sovereign debt crises, numerous banks experienced economic and liquidity distress and were subsequently bailed out by governments. However, bail-out is generally assumed to have negative externalities and adverse consequences for the economy, mainly in the light of the moral hazard hypothesis (see, among others, Dam \& Koetter, 2012; Dewatripont, 2014; Allen et al., 2015; Gornicka \& Zoican, 2016; Chari \& Kehoe, 2016).

In order to prevent future bail-outs and preserve financial stability and public finances, regulatory reforms and international standards, such as the EU Bank Recovery and Resolution Directive (BRRD Directive 2014/59/EU) and the Single Resolution Mechanism regulation (SRM 806/2014 EU) have been adopted.

According to the new rules, effective in the Euro-Area since January 2016, "bail-in" is one of the resolution tools that authorities can apply to deal with bank crisis (for a review see Wojcik, 2016). Failing banks can be recapitalized and losses can be absorbed by writing down shareholders and creditors claims and/or converting bonds into equity (Zhou et al., 2012). The contribution of bail-in to loss absorption and recapitalisation has to be equal to at least $8 \%$ of the total liabilities of the bank, and it can be applied independently or in combination with other resolution instruments. The bail-in regulation prescribes that all liabilities of a bank are "bailinable" except specific protected positions, such as secured liabilities (including covered bonds), covered deposits (deposits of up to one hundred thousand euro per capita) and interbank liabilities with an original maturity of less than seven days. These debts are explicitly excluded from the bail-in tool and thus defined as "non-bailinable" instruments. The bail-in regulations enforce loss absorption by "bailinable" instruments, following a specific hierarchy of claims. In line with the mechanisms applied in normal insolvency proceedings, the sequence of liabilities subject to bailin involves the reduction of Common Equity Tier 1 (CET1), Additional Tier 1 (AT1), Upper and Lower Tier 2 (T2), followed by the rest of eligible liabilities such as unsecured bonds not included in regulatory capital and noncovered deposits.

The research aims to verify how the differences in terms of yield between bonds have been impacted by the bailin legislation. In particular, the paper verifies how bond-specific and bank-specific features affect risk premiums in the light of the new bail-in procedure.

Specifically, the analysis sheds light on the following research questions: a) How did the risk premium for unsecured bonds increase with the introduction of the bail-in procedure compared to the risk premium for secured bonds? b) How did the risk premium for subordinated unsecured bonds increase with the introduction of the bail- 
in procedure compared to the risk premium for senior bonds? c) How did the risk premium for banks' leverage increase after the introduction of the bail-in procedure?

We contribute to existing literature by extending the strand on market discipline, assessing the impact of the introduction of bail-in on bonds returns for securities traded on secondary markets. In particular, we split the bailin effects on risk premiums into three main aspects: the "bailinable" status of the bond, the level of the bail-in hierarchy covered by the bond, and the level of bond issuers' leverage.

Unlike many other papers, we analyze yields and yield spreads on secondary markets, as does Giuliana, (2019). Moreover, unlike previous research, this study verifies the impact of the introduction of bail-in on debt yields considering the potential effective losses for bondholder in the case of bail-in, given the bank leverage, as well as the probability of the bail-in event for a bondholder, given the bond seniority level, as does Pablos (2019).

Overall, with a sample of 4,855 bonds issued by significant supervised European banks over the period 2006-2016, we find a positive association between bond returns and the status of "bailinable" security, which was enhanced in 2016. In addition, moving from secured to the riskiest bonds in the bail-in hierarchy, we find in particular a positive and significant relationship between bond returns and the second level of bond seniority in 2016, when bail-in regulations came into force. In fact, in 2016 the characteristics of being senior and unsecured had a stronger impact on yields than characteristics of being subordinated and unsecured, or senior and secured. Senior unsecured bondholders have seen on average greater yields as a reward for their additional risk since bail-in was introduced. Lastly, we find a positive association between bond returns and the severity of potential losses for bondholders which is related to the leverage of the bond issuer, in particular since 2016 when bail-in became applicable.

The paper is structured as follows. Section 2 presents the bail-in framework, the review of the related literature and testable hypotheses. Section 3 describes the methodology adopted and the sample. Section 4 discusses the main findings and Section 5 concludes with a discussion of the implications for investors, financial managers, and regulators.

\section{Related Literature and Hypotheses}

There is a great deal of literature on bail-in, with some authors discussing how the procedure should be designed from a theoretical perspective (Huertas, 2013, Avgouleas et al., 2013), and others noting the benefits of the bail-in mechanism compared to government assistance for banks (Allen et al., 2015, Pigrum et al., 2016; Philippon and Salord, 2017; Berger et al., 2018). Another strand of literature emphasizes the risks and limits of the procedure (Avgouleas and Goodhart, 2015; Leone et al., 2019; Da-Rocha-Lopes et al., 2018).

Klimek et al. (2015) highlight that the bail-in mechanism is the most efficient tool for crisis resolution for economies in recession with high unemployment. Wojcik (2016) emphasizes that bail-in affects decisively the financing of banks and the design of their corporate structure, but its effectiveness depends on its predictability and its legal stability.

Boccuzzi et al. (2017), examining the first application of the BRRD in Italy (2015) to four small to medium-sized failing banks, underline that resolution works best when the crisis is not systemic and the risk of a resorting to bail-out is still very high. Furthermore, Chennells and Wingfield (2015) note that bail-in is not the "silver bullet that ends the too big to fail issue", but it will make banks' funding costs more risk-sensitive.

Assessing the implementation of the bail-in tool in Europe, Eliasson et al. (2014), Chennells et al. (2015), Laviola et al. (2015) and Halaj et al. (2016), demonstrate that losses of banks under resolution usually exceed the existing equity capital. Bail-in thus affects subordinated bondholders, as well as shareholders, reducing the value of their bonds or converting their securities into shares.

Additionally, with a multi-layered network model on the securities holdings of the 26 largest Euro-Area banking groups, Hüser et al. (2017) find that subordinated creditors will always be affected by bail-in, while senior unsecured creditors will be affected in $75 \%$ of cases.

Conlon and Cotter (2014) look at the bail-in framework retrospectively, in the context of the European banking system during the global financial crisis, and suggest that equity and subordinated bondholders were the main losers from the 535 billion euro impairment losses made by failed banks.

Since the purpose of this research is to measure the relationship between bonds yields and bail-in risk, our hypotheses are based on the extensive literature on market discipline. In this framework, many authors (for example Morgan and Stiroh, 2000; Jagtiani et al., 2002; Covitz et al., 2004; Balasubramnian et al., 2011) assess the link between bank funding costs and their risks, indicating higher bond prices and yield risk sensitivity as a consequence of additional risks faced by banks. Among these, Flannery et al. (1996) and Sironi (2003) examine 
the yield-risk relationship after government decrees or new legislation.

In particular, Schafer et al. (2016) investigate market discipline after bail-in introduction by looking at the reaction of bank stocks prices to announcements of potential bail-in, finding evidence of increased CDS spreads and lower stock prices after five bail-in events in Europe between 2011 and 2014. Leone et al. (2019) demonstrate that in 2016 the model for stock market volatility changes, and these changes possibly reflect the introduction of the BRRD. Regarding the bond market, Giuliana (2019), demonstrating that bail-in increases investors' incentives to incorporate the bank's default probability into the price of its bonds, finds an improvement in market discipline. Crespi and Mascia (2018) show that, since the adoption of the BRRD, Italian banks have offered higher yields to bondholders, with the consequence of an increase in their cost of funding. Lastly, Crespi et al. (2019) demonstrate an increase of the spread between bailinable and non-bailinable bonds at issuance; their results support the hypothesis of improved market discipline for the bank bond primary market.

Following the literature on market discipline after the introduction of bail-in, this research analyses the regulatory provisions able to produce the most significant market effects. It verifies the impact of the classification of bonds as "bailinable" or "non-bailinable" and investigates the rule ranking bailinable bonds in a hierarchy, which determines the probability of bail-in on the basis of bond characteristics in terms of seniority.

Following the literature, we expect that the introduction of the bail-in will entail an increase in the yield of unsecured bonds compared to secured ones (non-bailinable bonds). Indeed, since BRRD implementation, unsecured bondholders can no longer rely on the implicit insurance of too-big-to-fail, according to which banks were generally bailed-out.

H1: The introduction of the bail-in procedure in the EU has increased the yields for unsecured bonds as well as the spread between yields of "bailinable" and "non-bailinable" bonds.

Secondly, focusing on "bailinable" bonds, we aim to verify whether the introduction of the bail-in hierarchy has enhanced the differences in bond yields according to their seniority. Starting from 2016, the degree of seniority of a bond has also become relevant in the case of resolution of the issuer: the level of seniority of creditors affects the probability that their security is effectively written down or converted in the case that the issuer is bailed-in. When bail-in became applicable, the risk faced by subordinated unsecured bondholders increased compared to the risk of senior unsecured bondholders, other things being equal. We thus expect that the positive link between bonds yields and the third level of seniority of bonds has become stronger since 2016.

$\mathrm{H} 2$ : The introduction of the bail-in procedure in the EU has increased the yields for subordinated unsecured bonds more than the yields for senior bonds. As a consequence, the spread between yields of "bailinable" and "nonbailinable" bonds has increased according to the seniority of bailinable securities.

The level of risk for a bondholder in the case of bank resolution depends on bank leverage, rather than characteristics of the bond. Bank leverage in fact affects the loss-absorbing capacity of the financial institution. When a bank covers a small percentage of liabilities (less than $8 \%$ ) with equity and subordinated bonds admitted to regulatory capital (own funds), it presents a low loss-absorbing capacity in the case of resolution. Senior bondholders, like subordinated bondholders not included in regulatory capital, will be effectively involved in covering losses: their losses in the case of bail-in will be more severe. We expect that the relationship between bank's capital structure and bond yields/bond yield spread will have become stronger since 2016. In other words, we expect a specific "bail-in severity" premium for issuers who are not able to absorb losses only with regulatory capital where bail-in is applied, especially since 2016. In fact, from the point of view of bondholders, yields should reflect the substantial effective losses in the case of bail-in, as well as the formal "bailinable" status of the bond and the specific level in the bail-in hierarchy.

H3: The introduction of the bail-in procedure in the Euro-Area has increased bond yields and the yield spread between "bailinable" and "non-bailinable" bonds according to the leverage level of the issuer.

Therefore, our hypotheses imply the effective functioning of market discipline. This may be even truer as transparency towards the market increases, with reference to the characteristics of issued bonds and the structure of regulatory capital (Bhattacharya et al. 1998; Granja, 2018). In particular, banks should disclose not only the characteristics of each security, in terms of seniority and ability to absorb losses, but also the overall structure of bank capital at the time of issue of the security. As stated by the literature, transparency regulation is able to promote and strengthen market discipline, in particular when it is associated with a shrinkage or the abolition of a financial safety net, as the case of bail-in introduction (Enoch et al., 1997; Demirguc-Kunt \& Huizinga, 1999). Favouring the functioning of market discipline, the enhancement of financial intermediaries' transparency is associated with greater bank stability (Bushman, 2016) as well as the improvement in the functioning of the 
banking system (Acharya \& Ryan, 2016; DeYoung et al., 2015).

According to our hypotheses, the introduction of the bail-in procedure increases the yields for unsecured bonds, in particular for subordinated unsecured ones. As a consequence, this regulation can affect bank funding costs. Nevertheless, a wide strand of literature found that an effective disclosure regulation is able to reduce the cost of capital for banks (Diamond \& Verrecchia, 1991; Francis et al., 2005; Lambert et al., 2007), potentially compensating the increase due to the bail-in risk.

\section{Research Design}

\subsection{Sample}

The sample comprises an unbalanced panel of 4,855 bonds issued by 45 significant supervised European banks over the period 2006-2016. In order to increase the level of representativeness of our sample, we consider the list of significant supervised entities of the European Central Bank (ECB) at 01/01/2017 (cut-off date for significance decisions) and therefore under the ECB's direct supervision. The sample includes all the significant supervised banks with outstanding bonds and complete available data for the period analysed (Note 1). The sample includes all their outstanding bonds, during the analysed period, issued both before and after 2006 . We select the outstanding bonds of holding companies and, when these are unavailable, the bonds of the main subsidiaries. All bonds in the sample expire on a date later than January 1, 2016, in order to analyze the effect of the introduction of bail-in.

Data on annual financial variables and bond yields are collected from Datastream (both Eikon and DFO). We collect monthly bond yields data from January 31st, 2006 to December 31st, 2016 and then determine their annual average. The size of the final sample is restricted to all the significant banks with available financial and yield variables. Our analyses are based on a final sample of 16,484 observations.

\subsection{Model Specification and Variables Definition}

We employ bond yields to maturity (Note 2), computed as the annual average of monthly yields to maturity, as the main dependent variable of our panel regressions. Additionally, we also determine bond yield spread estimated as the difference between "bailinable" bond yield to maturity and the average of "non-bailinable" bond yield to maturity.

As reported in Table 1, three main independent variables are studied to test our hypotheses. In line with the bailin creditor hierarchy, "bailinable" status is a dummy variable that takes a value of 1 if the bond is classified among the categories included in the bail-in procedure, and 0 otherwise. "Non-bailinable" bonds are those classified as "Senior secured", "Secured", "Senior secured - mortgage", "Mortgage", "Senior subordinated secured" or "Subordinated Secured".

With the aim of assessing the link between the bond return and its "bailinable" seniority, we create a "bail-in hierarchy" variable. It takes a value of 1 if the bond is classified as secured, a value of 2 if it is classified as a senior unsecured instrument and a value of 3 if the bond is classified among the subordinated unsecured securities.

Moreover, starting from the Minimum Requirement for own funds and Eligible Liabilities (MREL indicators) introduced in the BRRD, and from the Total Loss-Absorbency Capacity requirements (TLAC standard) introduced by the Financial Stability Board for global systemically important banks, we use a regressor to capture the severity of losses for bondholders due to application of the bail-in procedure. In particular, the variable "bail-in severity" measures losses in the case of bail-in for senior bondholders, as well as subordinated bondholders not included in regulatory capital. According to the first step of the bail-in procedure, the minimum amount of losses covered by "bailinable" securities is equal to $8 \%$ of the total liabilities of a bank. For a senior bondholder, the severity of losses in the case of bail-in depends on the portion of liabilities covered by regulatory capital. The risk for senior bondholders can be determined with reference to the previous classes in the bail-in hierarchy, through 1 minus the leverage ratio given by the sum of Tier 1 and Tier 2 over total liabilities. The higher the leverage ratio, the lower the losses given bail-in for senior unsecured bondholders and subordinated investors not holding capital instruments, and vice versa.

As a result, the "bail-in severity" variable is defined as:

$$
\text { Bail-in Severity }=(1-((\text { Tier } 1+\text { Tier2 }) / \text { Total liabilities })) * 100
$$

The higher the value of this variable, the higher bondholder losses in the case of bail-in.

In addition, in line with the literature (e.g. Jagtiani et al., 2002), as bond specific control variables we employ the time to maturity (the difference between maturity date (Note 3 ) and current date), the natural logarithm of the bond issued amount, and the coupon (the interest rate of a bond expressed as a percentage of the principal amount). As bank control variables, we use the pre-tax return on equity (ROE) for bank economic performance, the natural 
logarithm of total assets for bank size, and the ratio of loan loss reserves over non-performing loans as a measure of bank risk. We also use a dummy variable that takes the value of 1 if the bank is from Portugal, Ireland, Italy, Greece or Spain (PIIGS countries), and 0 otherwise, assuming higher yields for PIIGS countries where governments are in a weaker financial position. Lastly, as a macroeconomic proxy of the interest rate trend, for all the European banks' bonds analysed, we link the risk-free rate associated with the time to maturity of the bond by using the weighted average of Risk-free (EURIRS) and REPO, with time to maturity as a weight (Note 4).

Table 1 also reports the summary statistics of all the key variables for the panel period 2006-2016. The first and second columns give details of bond yields to maturity and spread between bond yields. Their mean and median values indicate a moderate rate of financial performance, with substantial variation over the period, as shown by the maximum and minimum values. In line with their financial characteristics, and in line with the literature on market discipline, the average value of bond yield spread indicates that "non-bailinable" bonds have lower yields than the "bailinable" ones. The summary statistics of "bail-in severity", with a median value of $93.11 \%$ and a maximum value of $98.27 \%$, exhibit potential senior bondholder losses in the case of bail-in, given that in the first step of the procedure "bailinable" securities have to cover at least $8 \%$ of the total liabilities of a bank. Considering the "BLNB" dummy variable, it can be observed that from 2006 to 2016, 76.28\% of bond observations are "bailinable". Lastly, the control variables indicate substantial variation across the European banks and their bonds, which present, for example, a time to maturity of minimum 1 year and maximum 40 years, and an average coupon rate of $2.06 \%$, which can however exceed $9 \%$.

Table 1. Definition of variables and descriptive statistics (Common sample)

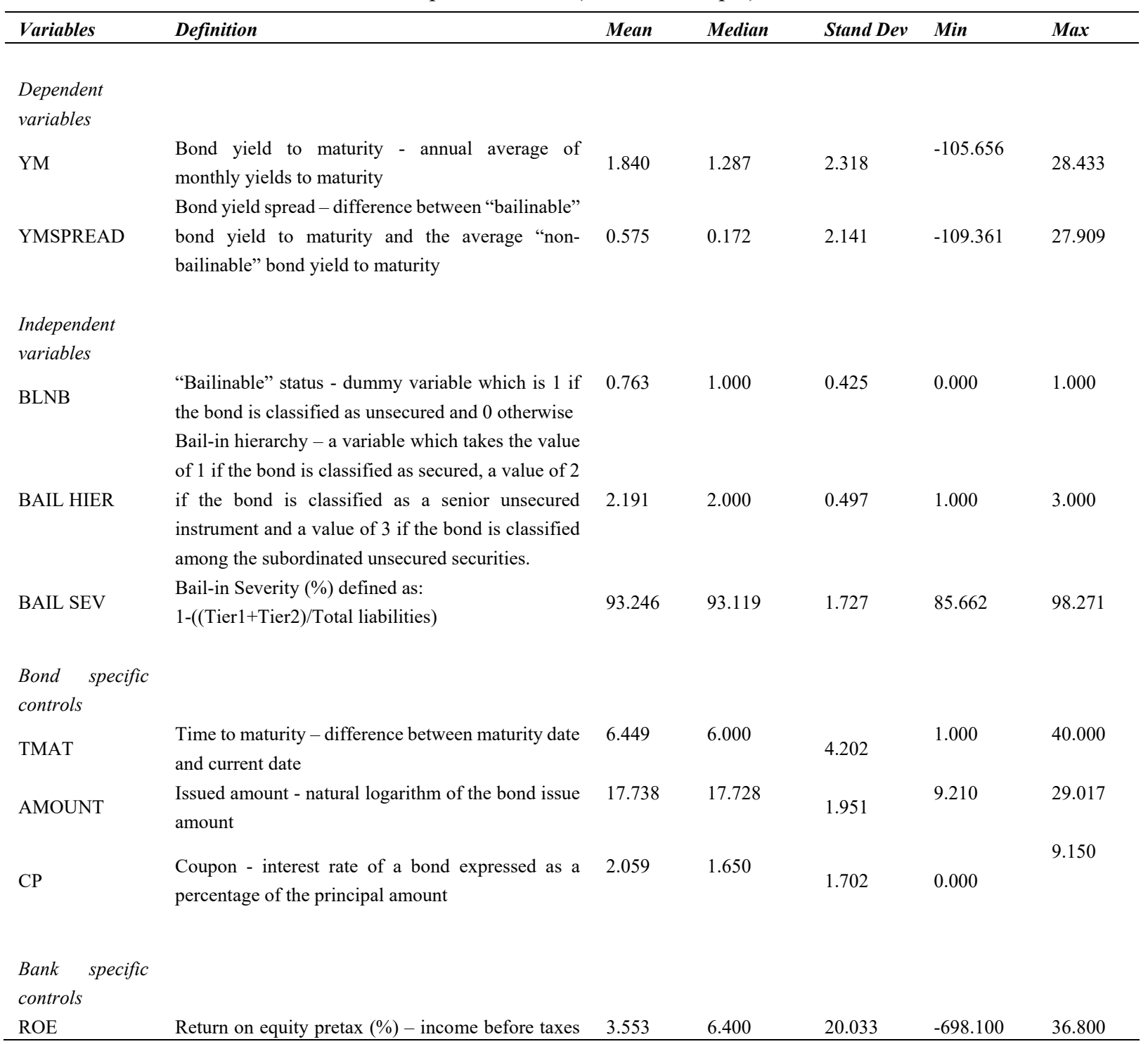




\begin{tabular}{|c|c|c|c|c|c|c|}
\hline & over equity & & & & & \\
\hline \multirow[t]{2}{*}{ BSIZE } & Bank size - Natural logarithm of total assets & \multirow{2}{*}{$\begin{array}{l}12.328 \\
0.867\end{array}$} & \multirow[t]{2}{*}{12.246} & \multirow[t]{2}{*}{0.887} & \multirow[t]{2}{*}{9.549} & \multirow[t]{2}{*}{14.605} \\
\hline & Weighted average of Risk-free (EURIRS) and & & & & & \\
\hline \multirow[t]{2}{*}{ RF-REPO } & $\begin{array}{l}\text { REPO with time to maturity as weights defined as: } \\
((10-\mathrm{TMAT}) * \mathrm{REPO}+\mathrm{TMAT} * \text { Risk-free }) / 10 \text { and }\end{array}$ & & \multirow[t]{2}{*}{0.547} & \multirow[t]{2}{*}{0.830} & \multirow[t]{2}{*}{0.062} & \multirow[t]{2}{*}{4.545} \\
\hline & $\begin{array}{l}\text { RFREPO }= \\
\text { free* }(\text { TMAT }>10)\end{array}$ & \multirow{3}{*}{0.181} & & & & \\
\hline \multirow[b]{2}{*}{ PIIGS } & PIIGS - DUMMY VARIABLE THAT TAKES 1 IF & & & & & \\
\hline & $\begin{array}{l}\text { THE BANK IS FROM PORTUGAL, IRELAND, } \\
\text { ITALY, GREECE OR SPAIN, AND } 0 \\
\text { OTHERWISE }\end{array}$ & & 0.000 & 0.385 & 0.000 & 1.000 \\
\hline
\end{tabular}

Note. This table reports the mean, median, maximum, minimum and standard deviation for all the outstanding bonds and the 45 European banks over the period 2006-2016 (common sample), for bond yields to maturity (YM), bond yield spread (YM SPREAD), "bailinable" status dummy variable (BLNB), "bail-in hierarchy" (BAIL HIER) and "bail-in severity" (BAIL SEV) in the first section. It reports the descriptive statistics for bond time to maturity (TMAT), bond issued amount (AMOUNT), bond coupons (CP), bank return on equity (ROE), bank size (BSIZE), PIIGS dummy variable (PIIGS) and the weighted average of risk-free (EURIRIS) and REPO (RF_REPO) in the second part. The number of observations is equal to 16,484 for all variables.

\subsubsection{Methodology}

Using data on all the outstanding bonds issued by each of the 45 important supervised European banks, we carry out pooled ordinary-least-squares regression analyses with the aim of determining the association between bond yields and bond yield spreads with "bailinable" bond status, bail-in hierarchy variable and the measure of bondholders "bail-in severity". In general, the study aims to assess the relationship between bond yields (or yield spread) and bond/bank characteristics related to the probability and the severity of bail-in, in particular in the period since the bail-in procedure was introduced.

The methodology is based on panel regression analyses and the hypotheses are tested through the following general model:

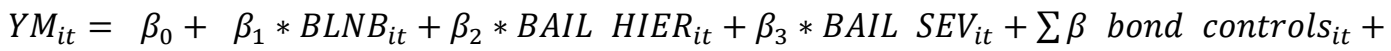

$$
\begin{aligned}
& \sum \beta \text { bank controls } i t+\varepsilon_{i t}
\end{aligned}
$$

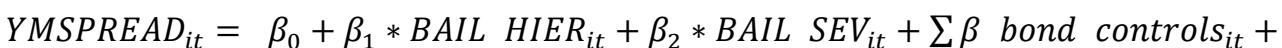

$$
\begin{aligned}
& \sum \beta \text { bank controls } i t+\varepsilon_{i t}
\end{aligned}
$$

where $\mathrm{i}$ represents bond $\mathrm{i}, \mathrm{t}$ represents year $\mathrm{t}$ and $\varepsilon_{i t}$ is the random error term of the model.

Using the variables defined in Table 1, the dependent variable of the equation is one of the two measures of bond yields presented above, and the independent variables are classified into two categories: major independent variables, which describe the three main bail-in characteristics investigated in this work, and, as controls, bond and bank specific variables which could influence bond yields.

The first step of the analysis examines the impact of bond "bailinable" status and "bail-in hierarchy" on bond yield to maturity separately. In the second step, we address the association between "bail-in severity" and bond yields. Furthermore, focusing only on "bailinable" bonds or on senior unsecured bonds, we investigate these associations only on these riskier securities. Lastly, in the third step, we test the link between the spread of "bailinable" and "non-bailinable" bond yields with the "bail-in hierarchy" and the "bail-in severity" variables defined above.

\section{Results}

\subsection{Bond Yields to Maturity as Dependent Variable}

Looking at the impact of bond "bailinable" status on bond yield, Table 2 reports the results of the first step of our models: pooled regression analyses with bond yield to maturity as dependent variable and bond "bailinable" status, or bond seniority, as the main independent variables. We consider also the interaction term between bond "bailinable" status and a dummy variable, which is one if year is equal to " 2016 " and 0 otherwise. 
Table 2. Model specifications with bond yields to maturity as dependent variable and "bailinable" status or "bailin hierarchy" as independent variables

\begin{tabular}{|c|c|c|c|c|c|c|c|}
\hline $\mathbf{Y M}$ & & I & II & III & IV & V (2016) & VI (2016) \\
\hline BLNB & & $\begin{array}{l}0.5432 * * * \\
(0.0298)\end{array}$ & & & & & \\
\hline BAIL HIER & & & & $\begin{array}{l}0.5584 * * * \\
(0.0252)\end{array}$ & & & \\
\hline BLNB * 2016 & & & $\begin{array}{l}0.6329 * * * \\
(0.0345)\end{array}$ & & & & \\
\hline BAILHIER=2 & & & & & $\begin{array}{l}0.4816^{* * *} \\
(0.0299)\end{array}$ & $\begin{array}{l}0.0539^{*} \\
(0.0315)\end{array}$ & \\
\hline BAILHIER=3 & & & & & $\begin{array}{l}1.3069^{* * *} \\
(0.0644)\end{array}$ & & $\begin{array}{l}-.2277 * * * \\
(0.0738)\end{array}$ \\
\hline TMAT & & $\begin{array}{l}0.0163 * * * \\
(0.0038)\end{array}$ & $\begin{array}{l}0.0082 * * \\
(0.0038)\end{array}$ & $\begin{array}{l}0.0136 * * * \\
(0.0038)\end{array}$ & $\begin{array}{l}0.0120^{* * *} \\
(0.0038)\end{array}$ & $-.0063(0.0084)$ & $-.0071(0.0084)$ \\
\hline AMOUNT & & $\begin{array}{l}-.00628^{* * *} \\
(0.0075)\end{array}$ & $\begin{array}{l}-.0636^{* * *} \\
(0.0075)\end{array}$ & $\begin{array}{l}-.0660^{* * * *} \\
(0.0074)\end{array}$ & $\begin{array}{l}-.0677 * * * \\
(0.0074)\end{array}$ & $0.0074(0.0079)$ & $0.0090(0.0079)$ \\
\hline $\mathrm{CP}$ & & $\begin{array}{l}0.0854 * * * \\
(0.0080)\end{array}$ & $\begin{array}{l}0.0845^{* * *} \\
(0.0080)\end{array}$ & $\begin{array}{l}0.0681 * * * \\
(0.0079)\end{array}$ & $\begin{array}{l}0.0583 * * * \\
(0.0082)\end{array}$ & $\begin{array}{l}-.1107 * * * \\
(0.0094)\end{array}$ & $\begin{array}{l}-.1066^{* * *} \\
(0.0095)\end{array}$ \\
\hline $\mathrm{ROE}(\mathrm{t}-1)$ & & $\begin{array}{l}-.0055^{* * *} \\
(0.0007)\end{array}$ & $\begin{array}{l}-.0065 * * * \\
(0.0007)\end{array}$ & $\begin{array}{l}-.0059^{* * * *} \\
(0.0007)\end{array}$ & $\begin{array}{l}-.0061 * * * \\
(0.0007)\end{array}$ & $\begin{array}{l}-.0151^{* * *} \\
(0.0023)\end{array}$ & $\begin{array}{l}-.0143 * * * \\
(0.0023)\end{array}$ \\
\hline BSIZE & & $\begin{array}{l}-.0301^{*} \\
(0.0160)\end{array}$ & $-.0197(0.0159)$ & $\begin{array}{l}-.0435^{* * *} \\
(0.0159)\end{array}$ & $\begin{array}{l}-.0462 * * * \\
(0.0159)\end{array}$ & $-.0165(0.0159)$ & $-.0088(0.0159)$ \\
\hline PIIGS & & $\begin{array}{l}1.0194 * * * \\
(0.0386)\end{array}$ & $\begin{array}{l}0.9910^{* * *} \\
(0.0386)\end{array}$ & $\begin{array}{l}1.0353 * * * \\
(0.0385)\end{array}$ & $\begin{array}{l}1.0368^{* * *} \\
(0.0384)\end{array}$ & $\begin{array}{l}-.1099 * * * \\
(0.0437)\end{array}$ & $\begin{array}{l}-.1232 * * * \\
(0.0435)\end{array}$ \\
\hline RF-REPO & & $\begin{array}{l}0.4381 * * * \\
(0.0218)\end{array}$ & $\begin{array}{l}0.5662 * * * \\
(0.0236)\end{array}$ & $\begin{array}{l}0.4475 * * * \\
(0.0217)\end{array}$ & $\begin{array}{l}0.4452^{* * *} \\
(0.0216)\end{array}$ & $\begin{array}{l}-1.6420 * * * \\
(0.2176)\end{array}$ & $\begin{array}{l}-1.6115^{* * *} \\
(0.2176)\end{array}$ \\
\hline YM (t-1) & & $\begin{array}{l}0.4963 * * * \\
(0.0073)\end{array}$ & $\begin{array}{l}0.5115^{* * * *} \\
(0.0072)\end{array}$ & $\begin{array}{l}0.4842 * * * \\
(0.0074)\end{array}$ & $\begin{array}{l}0.4818^{* * *} \\
(0.0073)\end{array}$ & $\begin{array}{l}1.4061^{* * *} \\
(0.0104)\end{array}$ & $\begin{array}{l}1.4164 * * * \\
(0.0105)\end{array}$ \\
\hline Intercept & & $\begin{array}{l}1.0517 * * * \\
(0.1985)\end{array}$ & $\begin{array}{l}1.0913 * * * \\
(0.1984)\end{array}$ & $\begin{array}{l}0.7461 * * * \\
(0.1984)\end{array}$ & $\begin{array}{l}1.4476^{* * *} \\
(0.1996)\end{array}$ & $0.2426(0.2065)$ & $0.1384(0.2102)$ \\
\hline Cross sections & & 4855 & 4855 & 4855 & 4855 & 4778 & 4778 \\
\hline Tot. Obs. & & 15095 & 15095 & 15095 & 15095 & 4778 & 4778 \\
\hline R-squared & & 0.4932 & 0.4933 & 0.4984 & 0.4991 & 0.8291 & 0.8293 \\
\hline $\begin{array}{l}\text { Adjusted } \\
\text { squared }\end{array}$ & R- & 0.4929 & 0.4930 & 0.4981 & 0.4988 & 0.8287 & 0.8290 \\
\hline Durbin Watson & & 1.6722 & 1.7177 & 1.6589 & 1.6554 & & \\
\hline
\end{tabular}

Note. This table reports the regression results using pooled ordinary-least-squares between bond yields and bond "bailinable" status in the first and second columns, and "bail-in hierarchy" in all the others. Columns V and VI present the regression results for the year 2016 only. The dependent variable is bond yields to maturity (YM). The explanation variables are: "bailinable" status dummy variable (BLNB), "bail-in hierarchy" (BAIL HIER), bond time to maturity (TMAT), bond issued amount (AMOUNT), bond coupons (CP), bank return on equity (ROE), bank size (BSIZE), PIIGS dummy variable (PIIGS) and the weighted average of risk-free (EURIRS) and REPO (RF-REPO). All regressions are estimated with robust standard errors that are reported in parentheses. ${ }^{* *}, * *, *$ indicate statistical significance at $1 \%, 5 \%$ and $10 \%$, respectively. The number of observations varies due to data availability.

In the third column "bail-in hierarchy" is the main regressor and in the fourth one it shows the regression results between bond yields and the riskier levels of bail-in hierarchy. Columns V and VI report the results for the second and the third level of the hierarchy in 2016 respectively.

The results show that "bailinable" bonds' status and "bail-in hierarchy" are always statistically significant and positively associated with bond yields to maturity over the period 2006-2016. In particular, if bonds are "bailinable" they increase their yields on average by $0.54 \%$, and moving along the levels of seniority, from senior bonds to subordinated ones, bond yields increase by $0.55 \%$. Furthermore, Column IV reports the significant and positive association between riskier bonds, the second and third levels of bail-in hierarchy, and bond yields over the period 2006-2016. This is consistent with the literature and confirms that, if a bond is unsecured and has a low level of seniority, bond yield increases in order to reward debt-holders for the additional risk compared to secured and senior bonds.

We next test our hypothesis on the impact of bail-in on returns, according to bond characteristics. The joint effect 
of "bailinable" bond status and year "2016" is positive on bond yields and indicates on average increased level of bond yields. Moreover, we separately analyse the association between each level of the hierarchy and bond yield in 2016. Columns V and VI of Table 2 show that bond yields are associated with creditors' level in the hierarchy of the bail-in mechanism. Specifically, Column V shows that this association, for the second level of the hierarchy, has been positive and significant $(+0.05 \%)$ since 2016 when bail-in came into force, while Column VI shows that subordinated unsecured bonds (the third level of the hierarchy) are significantly but negatively related with bond yields in 2016. After bail-in introduction, only the second level of the hierarchy has a positive and significant impact on bond yields to maturity, proving that senior unsecured bondholders have seen average greater yields as reward for their additional risk since bail-in came into force (Note 5). Thus, considering bond yields to maturity as dependent variable, $\mathrm{H} 1$ is confirmed, whilst $\mathrm{H} 2$ is rejected. The coefficients of determination " $\mathrm{R}$ squared" and "adjusted R-squared" indicate that all the models have a good capacity to explain the variance of the dependent variables, especially in 2016. Table 3 shows the results of the panel regression analyses with "bail-in severity" as the main regressor.

Table 3. Model specifications with bond yields to maturity as dependent variable and "bail-in severity" and/or "bail-in hierarchy" as independent variables

\begin{tabular}{|c|c|c|c|c|c|c|}
\hline YM & $\mathbf{I}$ & II (2016) & III (2016) & $\begin{array}{l}\text { IV } \\
\text { (BNLB) }\end{array}$ & $\begin{array}{l}\text { V } \\
(\text { HIER=2) }\end{array}$ & $\begin{array}{l}\text { VI (2016) } \\
(\text { HIER=2) }\end{array}$ \\
\hline BAIL HIER =2 & & & $\begin{array}{l}0.0885^{* * * *} \\
(0.0317)\end{array}$ & & & \\
\hline BAIL HIER & & & & $\begin{array}{l}0.8240 * * * \\
(0.0909)\end{array}$ & & \\
\hline BAIL SEV & $\begin{array}{l}0.0212 * \\
(0.0116)\end{array}$ & $\begin{array}{l}0.0838^{* * *} \\
(0.0092)\end{array}$ & $\begin{array}{l}0.0862 * * * \\
(0.0092)\end{array}$ & $\begin{array}{l}0.0508^{* * *} \\
(0.0149)\end{array}$ & $\begin{array}{l}0.0406 * * * \\
(0.0159)\end{array}$ & $\begin{array}{l}0.1090^{* * *} \\
(0.0117)\end{array}$ \\
\hline TMAT & $\begin{array}{l}0.0157 * * * \\
(0.0049)\end{array}$ & $\begin{array}{l}-.0059 \\
(0.0083)\end{array}$ & $\begin{array}{l}-.0044 \\
(0.0083)\end{array}$ & $\begin{array}{l}0.0271 * * * \\
(0.0066)\end{array}$ & $\begin{array}{l}0.0271 * * * \\
(0.0073)\end{array}$ & $\begin{array}{l}-.0232 * \\
(0.0121)\end{array}$ \\
\hline AMOUNT & $\begin{array}{l}-.0647 * * * \\
(0.0091)\end{array}$ & $\begin{array}{l}0.0009 \\
(0.0079)\end{array}$ & $\begin{array}{l}0.0021 \\
(0.0080)\end{array}$ & $\begin{array}{l}-.0562 * * * \\
(0.0123)\end{array}$ & $\begin{array}{l}-.0555 * * * \\
(0.0130)\end{array}$ & $\begin{array}{l}-.0010 \\
(0.0102)\end{array}$ \\
\hline $\mathrm{CP}$ & $\begin{array}{l}0.0659 * * * \\
(0.0099)\end{array}$ & $\begin{array}{l}-.1140 * * * \\
(0.0091)\end{array}$ & $\begin{array}{l}-.1080 * * * \\
(0.0094)\end{array}$ & $\begin{array}{l}0.0583 * * * \\
(0.0137)\end{array}$ & $\begin{array}{l}0.0638^{* * *} \\
(0.0149)\end{array}$ & $\begin{array}{l}-.1231 * * * \\
(0.0126)\end{array}$ \\
\hline $\operatorname{ROE}(\mathrm{t}-1)$ & $\begin{array}{l}-.0133 * * * \\
(0.0013)\end{array}$ & $\begin{array}{l}-.0115 * * * \\
(0.0023)\end{array}$ & $\begin{array}{l}-.0115^{* * *} \\
(0.0023)\end{array}$ & $\begin{array}{l}-.0151 * * * \\
(0.0016)\end{array}$ & $\begin{array}{l}-.0150 * * * \\
(0.0017)\end{array}$ & $\begin{array}{l}-.0099 * * * \\
(0.0028)\end{array}$ \\
\hline BSIZE & $\begin{array}{l}-.0329 \\
(0.0229)\end{array}$ & $\begin{array}{l}-.1099 * * * \\
(0.0197)\end{array}$ & $\begin{array}{l}-.1149 * * * \\
(0.0198)\end{array}$ & $\begin{array}{l}-.1020 * * * \\
(0.0309)\end{array}$ & $\begin{array}{l}-.0840 * * * \\
(0.0333)\end{array}$ & $\begin{array}{l}-.1222 * * * \\
(0.0268)\end{array}$ \\
\hline PIIGS & $\begin{array}{l}0.9318^{* * *} \\
(0.0469)\end{array}$ & $\begin{array}{l}-.1103 * * * \\
(0.0431)\end{array}$ & $\begin{array}{l}-.0971 * * \\
(0.0433)\end{array}$ & $\begin{array}{l}1.2390^{* * *} \\
(0.0611)\end{array}$ & $\begin{array}{l}1.3135 * * * \\
(0.0650)\end{array}$ & $\begin{array}{l}-.3790 * * * \\
(0.0564)\end{array}$ \\
\hline RF-REPO & $\begin{array}{l}0.4136^{* * *} \\
(0.0283)\end{array}$ & $\begin{array}{l}-1.6937 * * * \\
(0.2166)\end{array}$ & $\begin{array}{l}-1.7054 * * * \\
(0.2165)\end{array}$ & $\begin{array}{l}0.3616^{* * *} \\
(0.0376)\end{array}$ & $\begin{array}{l}0.3468 * * * \\
(0.0426)\end{array}$ & $\begin{array}{l}-1.5505^{* * * *} \\
(0.2990)\end{array}$ \\
\hline YM (t-1) & $\begin{array}{l}0.4719 * * * \\
(0.0084)\end{array}$ & $\begin{array}{l}1.4085^{* * *} \\
(0.0102)\end{array}$ & $\begin{array}{l}1.4036^{* * *} \\
(0.0103)\end{array}$ & $\begin{array}{l}0.3797 * * * \\
(0.0099)\end{array}$ & $\begin{array}{l}0.3633^{* * *} \\
(0.0102)\end{array}$ & $\begin{array}{l}1.5339 * * * \\
(0.0133)\end{array}$ \\
\hline Intercept & $\begin{array}{l}-.2702 \\
(0.9561)\end{array}$ & $\begin{array}{l}-6.2689^{* * *} \\
(0.7544)\end{array}$ & $\begin{array}{l}-6.5335^{* * *} \\
(0.7598)\end{array}$ & $\begin{array}{l}-3.7411 \text { *** } \\
(1.2101)\end{array}$ & $\begin{array}{l}-1.3613 \\
(1.2895)\end{array}$ & $\begin{array}{l}-8.5077^{* * *} \\
(0.9355)\end{array}$ \\
\hline Cross sections & 4656 & 4601 & 4601 & 3616 & 3417 & 3371 \\
\hline Tot. Obs. & 11958 & 4601 & 4601 & 8860 & 8273 & 3371 \\
\hline R-squared & 0.4243 & 0.8375 & 0.8377 & 0.3724 & 0.3326 & 0.8380 \\
\hline $\begin{array}{l}\text { Adjusted } \quad \text { R- } \\
\text { squared }\end{array}$ & 0.4239 & 0.8371 & 0.8374 & 0.3717 & 0.3319 & 0.8376 \\
\hline Durbin Watson & 1.9851 & & & 1.9193 & 1.9022 & \\
\hline
\end{tabular}

Note. This table reports the regression results using pooled ordinary-least-squares between bond yields and "bail-in severity" in the first and second columns. Column IV shows the results of the regression on "bailinable" bonds and Columns V and VI the regressions on the second level of the bail-in hierarchy. Columns II, III and VI present the regression results for the year 2016 only. The dependent variable is bond yields to maturity (YM). The explanation variables are: "bail-in hierarchy" (BAIL HIER), "bail-in severity" (BAIL SEV), bond time to maturity (TMAT), bond issued amount (AMOUNT), bond coupons (CP), bank return on equity (ROE), bank size (BSIZE), PIIGS dummy variable (PIIGS) and the weighted average of risk-free (EURIRS) and REPO (RF-REPO). All regressions are estimated with robust standard errors that are reported in parentheses. ${ }^{* * *},{ }^{* *}, *$ indicate statistical significance at $1 \%, 5 \%$ and $10 \%$, respectively. The number of observations varies due to data availability. 
Columns IV presents regression only on "bailinable" bonds while Columns V and VI show the analyses only on senior unsecured bonds (second level of "bail-in hierarchy"). Columns II, III and VI show results for the year 2016 only. As discussed above, the higher "bail-in severity" (resulting from low bank leverage), the higher bondholders losses in the case of bail-in. In all columns of Table 3, the measure is always significant and positively associated with bond yields, and the magnitudes of "bail-in severity" clearly increase as shown by the results of the regressions on "bailinable" bonds and on senior unsecured bonds. Investigating these associations only in the year when bail-in became applicable, $\mathrm{H} 3$ is confirmed considering the bond yields to maturity by the higher coefficients of "bail-in severity". For instance, by increasing "bail-in severity" by one percentage point, bond yields increase by nearly $0.05 \%$, while looking at only "bailinable" bonds and, more specifically, at the senior unsecured ones in 2016 , bond yields increase by nearly $0.10 \%$. This indicates that riskier banks with lower leverage make possible higher bond yields, especially for senior unsecured securities. The R squared, and the adjusted R squared, coefficients increase the goodness of fit of the models, especially in 2016.

The analysis of the impact of bond and bank control variables provides some interesting insights. In all the models, bond coupons are statistically significant and negatively associated with the yields as far as 2016 is concerned. In contrast, bond time to maturity is always positive and significantly related with bond yields, and the natural logarithm of the issued amount of all the bonds is inversely related with their yields, except in the 2016 specifications. Bank return on equity (Note 6) of the previous year is always significant and negatively linked with bond yields. In addition, yields of the previous year are always positively and significantly linked with bonds yields at time t, indicating a clear persistence over time. Lastly, the natural logarithm of banks' total assets (Note 7) is not always significant, while the PIIGS dummy variable is always significantly related with bond yields and has a positive influence, except in the 2016 specifications where it becomes negative.

\section{2 "Bailinable” and "non-bailinable” Bond Yield Spread as Dependent Variable}

The last step of the research investigates the impact of bail-in, in terms of "bail-in severity" and "bail-in hierarchy" variables, on the spread between "bailinable" and "non-bailinable" bond yields. Table 4 shows the results of all the specifications.

Table 4. Model specifications with "bailinable" and "non-bailinable" bond yield spread as dependent variable and "bail-in severity" and/or "bail-in hierarchy" as regressors

\begin{tabular}{|c|c|c|c|c|c|c|}
\hline YM SPREAD & $\mathbf{I}$ & II (2016) & III & IV (2016) & V (2016) & VI (2016) \\
\hline BAIL HIER & & & $\begin{array}{l}0.8417 * * * \\
(0.0909)\end{array}$ & & & \\
\hline BAIL SEV & $\begin{array}{l}0.0591 * * * \\
(0.0150)\end{array}$ & $\begin{array}{l}0.1011^{* * *} \\
(0.0117)\end{array}$ & $\begin{array}{l}0.0527^{* * *} \\
(0.0149)\end{array}$ & & $\begin{array}{l}0.1024 * * * \\
(0.0116)\end{array}$ & \\
\hline BAILHIER $=2$ & & & & $\begin{array}{l}0.3247 * * * \\
(0.0833)\end{array}$ & $\begin{array}{l}0.4005^{* * *} \\
(0.0810)\end{array}$ & \\
\hline BAILHIER=3 & & & & & & $\begin{array}{l}-.3246 * * * \\
(0.0833)\end{array}$ \\
\hline TMAT & $\begin{array}{l}0.0678^{* * *} \\
(0.0067)\end{array}$ & $\begin{array}{l}-.0169 \\
(0.0110)\end{array}$ & $\begin{array}{l}0.0635^{* * *} \\
(0.0067)\end{array}$ & $\begin{array}{l}-.0180 \\
(0.0113)\end{array}$ & $\begin{array}{l}-.0173 \\
(0.0110)\end{array}$ & $-.0180(0.0113)$ \\
\hline AMOUNT & $\begin{array}{l}-.0462 * * * \\
(0.0123)\end{array}$ & $\begin{array}{l}0.0066 \\
(0.0101)\end{array}$ & $\begin{array}{l}-.0544 * * * \\
(0.0123)\end{array}$ & $\begin{array}{l}0.0168^{*} \\
(0.0103)\end{array}$ & $\begin{array}{l}0.0131 \\
(0.0102)\end{array}$ & $\begin{array}{l}0.0168 * \\
(0.0103)\end{array}$ \\
\hline $\mathrm{CP}$ & $\begin{array}{l}0.0932 * * * \\
(0.0130)\end{array}$ & $\begin{array}{l}-.1453 * * * \\
(0.0116)\end{array}$ & $\begin{array}{l}0.0544 * * * \\
(0.0136)\end{array}$ & $\begin{array}{l}-.1280 * * * \\
(0.0125)\end{array}$ & $\begin{array}{l}-.1260 * * * \\
(0.0122)\end{array}$ & $\begin{array}{l}-.1280 * * * \\
(0.0125)\end{array}$ \\
\hline $\operatorname{ROE}(\mathrm{t}-1)$ & $\begin{array}{l}-.0144 * * * \\
(0.0016)\end{array}$ & $\begin{array}{l}-.0132 * * * \\
(0.0028)\end{array}$ & $\begin{array}{l}-.0155^{* * *} \\
(0.0116)\end{array}$ & $\begin{array}{l}-.0156^{* * * *} \\
(0.0029)\end{array}$ & $\begin{array}{l}-.0111 * * * \\
(0.0029)\end{array}$ & $\begin{array}{l}-.0156^{* * * *} \\
(0.0029)\end{array}$ \\
\hline BSIZE & $\begin{array}{l}-.1059 * * * \\
(0.0310)\end{array}$ & $\begin{array}{l}-.1452 * * * \\
(0.0264)\end{array}$ & $\begin{array}{l}-.1186 * * * \\
(0.0309)\end{array}$ & $-.0013(0.0207)$ & $\begin{array}{l}-.1327 * * * \\
(0.0264)\end{array}$ & $-.0013(0.0207)$ \\
\hline PIIGS & $\begin{array}{l}1.2248^{* * *} \\
(0.0611)\end{array}$ & $\begin{array}{l}-.2578 * * * \\
(0.0561)\end{array}$ & $\begin{array}{l}1.2060 * * * \\
(0.0608)\end{array}$ & $\begin{array}{l}-.2508 * * * \\
(0.0576)\end{array}$ & $\begin{array}{l}-.2555 * * * \\
(0.0559)\end{array}$ & $\begin{array}{l}-.2508 * * * \\
(0.0576)\end{array}$ \\
\hline RF-REPO & $\begin{array}{l}-.4076 * * * \\
(0.0375)\end{array}$ & $\begin{array}{l}-1.7360 * * * \\
(0.2785)\end{array}$ & $\begin{array}{l}-.4218 * * * \\
(0.0373)\end{array}$ & $\begin{array}{l}-1.6258 * * * \\
(0.2863)\end{array}$ & $\begin{array}{l}-1.6552 * * * \\
(0.2781)\end{array}$ & $\begin{array}{l}-1.6258 * * * \\
(0.2863)\end{array}$ \\
\hline $\begin{array}{c}\text { YM } \\
(\mathrm{t}-1)\end{array}$ & $\begin{array}{l}0.3947 * * * \\
(0.0098)\end{array}$ & $\begin{array}{l}1.4965^{* * *} \\
(0.0130)\end{array}$ & $\begin{array}{l}0.3833 * * * \\
(0.0098)\end{array}$ & $\begin{array}{l}1.5122 * * * \\
(0.0135)\end{array}$ & $\begin{array}{l}1.5106^{* * *} \\
(0.0132)\end{array}$ & $\begin{array}{l}1.5122 * * * \\
(0.0135)\end{array}$ \\
\hline Intercept & $-3.2318 * * *$ & $-6.8278 * * *$ & $-3.9424 * * *$ & 0.2737 & $-7.6771 * * *$ & $0.5984 * *$ \\
\hline
\end{tabular}




\begin{tabular}{lllllll}
\hline & $(1.2113)$ & $(0.9310)$ & $(1.2080)$ & $(0.2999)$ & $(0.9437)$ & $(0.2682)$ \\
$\begin{array}{l}\text { Cross } \\
\text { sections }\end{array}$ & 3616 & 3567 & 3616 & 3655 & 3567 & 3655 \\
$\begin{array}{l}\text { Tot. Obs. } \\
\text { R-squared }\end{array}$ & 8860 & 3567 & 8860 & 3655 & 3567 & 3655 \\
$\begin{array}{l}\text { Adjusted } \quad \text { R- } \\
\text { squared }\end{array}$ & 0.3012 & 0.8317 & 0.3079 & 0.8223 & 0.8329 & 0.8223 \\
Durbin Watson & 0.3005 & 0.8313 & 0.3071 & 0.8219 & 0.8324 & 0.8219 \\
\hline
\end{tabular}

Note. This table reports the regression results using pooled ordinary-least-squares between "bailinable" and "non-bailinable" bond yield spread and "bail-in severity" in the first two columns, "bail-in hierarchy" in Column III, the second level of the hierarchy in columns IV and V and the third level of the hierarchy in the last column. Columns II, IV, V and VI present the regression results for the year 2016 only. The dependent variable is bond yield spread (YM SPREAD). The explanation variables are: "bail-in hierarchy" (BAIL HIER), "bail-in severity" (BAIL SEV), bond time to maturity (TMAT), bond issued amount (AMOUNT), bond coupons (CP), bank return on equity (ROE), bank size (BSIZE), PIIGS dummy variable (PIIGS) and the weighted average of risk-free (EURIRS) and REPO (RF-REPO). All regressions are estimated with robust standard errors that are reported in parentheses. ${ }^{* *}, * *, *$ indicate statistical significance at $1 \%, 5 \%$ and $10 \%$, respectively. The number of observations varies due to data availability.

The key finding is that "bail-in severity" is always statistically significant and positively associated with the spread between "bailinable" bond yield and the average "non-bailinable" bond yield to maturity over the period 20062016. A higher level of "bail-in severity" leads to a greater yield spread between "bailinable" and "non-bailinable" bonds. Thus, considering the bonds yield spread as dependent variable, $\mathrm{H} 3$ is confirmed. Moreover, moving along the "bail-in hierarchy", from secured bonds to the riskiest ones, bond yield spread increases by nearly $0.85 \%$. Examining only the effect of senior unsecured bond seniority (second level of the hierarchy) and the subordinated unsecured bond seniority separately when bail-in came into force, they show a positive and negative relation with bond yield spread respectively. Specifically, consistent with the results of Table 2, in 2016 only senior unsecured bonds are significantly positively associated with bond yield spread and they have the strongest impact (nearly $+0.40 \%$ ). This indicates that, contrary to what we expected for subordinated unsecured bonds, senior unsecured bondholders have had on average greater yields as a reward for their additional risk since bail-in was introduced. As above, $\mathrm{H} 2$ is rejected.

Columns II, IV, V and VI show the regression results for 2016 only, when all the magnitudes of the coefficients increase. Furthermore, the coefficients of determination show a good capacity of all models to explain the variance of the dependent variables and, as before, they increase only for the year 2016. Lastly, for all the models, the Variance Inflation Factor is used to check the multicollinearity between variables. All regressors show a VIF lower than 1.8 , demonstrating no multicollinearity for any specifications.

\subsection{Robustness}

Other regression models are tested in order to analyse the robustness and validity of the findings.

First, in order to test whether yields are influenced by "bailinable" bonds' status, we carry out a panel regression analysis on only monthly bond yields, without including bank variables. In addition, we analyse the period 20142016 after the publication of the EU Bank Recovery and Resolution Directive, and before its entry into force, in order to check whether the market anticipated the bail-in effect. In particular, we investigate our measure of "bailin severity", looking at its impact on bond yields after the introduction of BRRD, and the association between riskier bonds, the second and third levels of bail-in hierarchy, and bonds yields over the period 2014-2016. Lastly, we carry out panel regression analyses with year and country fixed effect. Results (Note 8) indicate that all the bail-in independent variables are always significant and, thus consolidate the findings described above as well as the robustness of the measure of "bail-in severity".

\section{Conclusions and Implications}

Bail-in is one of the resolution tools that can be used by authorities to deal with banking crisis. As it permits the absorption of losses by writing down and/or converting shareholder and creditor claims into equity, it places "bailinable" (non-secured) and "non-bailinable" (secured) bondholders on different levels. Furthermore, "bailinable" securities can be used to cover losses following a specific hierarchy of claims, relating to the seniority of the instruments. Lastly, the application of a minimum amount of loss coverage for "bailinable" securities $(8 \%$ of total liabilities) leads to different levels of effective risk for debt-holders according to the specific leverage of the issuer. 
The aim of this paper is to analyze these three different bail-in issues, by addressing whether (a) "bailinable" bond status, (b) the levels of bond seniority in the bail-in hierarchy and (c) the specific "bail-in severity" for bondholders given by bank leverage, are associated with bond yield and yield spread, in particular since the introduction of the EU bail-in procedure.

With a sample of 4,855 bonds issued by 45 European significant supervised banks, we use pooled regression analysis on bond yields and on bond yield spread between "bailinable" and "non-bailinable" bonds.

Overall, three main results are found. First, "bailinable" bond status is always positively and significantly linked to bond yields and bond yield spread. The introduction of the bail-in procedure has increased the yield spreads between secured and unsecured bonds. In particular, if bonds are "bailinable" they increase their yields on average by $0.54 \%$.

Second, since the implementation of bail-in, the level of bond seniority has enhanced the effect on bonds yields and senior unsecured bondholders have the greatest and positive effect on bond yield $(+0.05 \%)$ and bond yield spread $(+0.32 \%)$. This is a significant result. According to the bail-in hierarchy, we expected a higher increase in yields for subordinated unsecured bonds, given their higher probability of being written-down or converted into stocks in the case of bail-in. Conversely, the high level of risk of subordinated unsecured bonds already perceived by the market did not generate a strong increase in yields at the time of the introduction of bail-in, while the lower risk perceived on senior unsecured bonds led to a noticeable increase on their returns in light of the new banking resolution legislation.

The third finding enriches the literature on market discipline: a specific "bail-in severity" premium, related to bank leverage, for all the bond yields and yield spread from 2006 to 2016 is identified. In fact, where "bail-in severity" increases by one per cent, bond yields increase by approximately $0.10 \%$; the effect of senior unsecured bondholders' seniority on the spread between "bailinable" and "non-bailinable" instruments are a rise of nearly $0.35 \%$. Furthermore, the relationship between the level of bank capitalization and bond yields increases more in the year in which bail-in came into force (2016). These findings show an increase in the risk premiums for bonds issued by Euro-Area banks, especially for banks with a low level of capitalisation.

These findings have important implications for private investors and financial managers, as well as for researchers and supervisors.

First, our results about bail-in risk premium can contribute to explain and interpret the yields of new classes of bonds. As an example, in December 2017 a fast-tracked amendment to the original regulation, called BRRD2, was published (European Directive No. 2017/2399). BRRD2 has been in force since January 1st 2019. This amendment revised the bank creditors' hierarchy in resolution and insolvency of financial institutions, through the introduction of a new category of liabilities, "senior non-preferred" bonds. This class lies between senior and subordinated unsecured creditors and includes all unsecured debt instruments with an original contractual maturity of at least one year, containing no embedded derivatives and not being derivatives themselves. Given our results, we expect a significant market effect of the bail-in regulation on "non-preferred" senior bonds, with a big impact on bank funding costs.

This market effect, due to the introduction of a revised hierarchy, can contribute to explain and influence investment decisions, regarding both the choose between the different categories of bonds issued by the same bank and the selection between the same category of bonds issued by banks with different leverage profiles.

According to our results, decisions regarding the level of bank capitalization are relevant for determining the bailin risk perceived by investors. The bail-in risk premium is higher for financial institutions with a low level of capitalization. In order to compensate the potential increase in bank funding costs, financial intermediaries are called to improve their level of disclosure. Indeed, according to the literature, an effective disclosure regulation is able to reduce the cost of capital for banks.

As capital and liquidity requirements were accompanied by the enhancement of bank transparency to promote safety and soundness in the banking system, our study calls a wider disclosure and a close attention of regulators and policymakers, for the purposes of protecting bank creditors after the introduction of bail-in procedure. Because the pricing of bond securities is significantly affected by the risk of bail-in, it is important that the issuing institutions make fully transparent the size of the various classes of liabilities intended to absorb losses. The "bailin severity" indicator, as a measure of total loss-absorbency capacity of a bank, could be included in the informative framework for bondholders, in order to raise awareness of the additional risks related to "bailinable" bonds. Indeed, it is important for an investor to know, other than the probability of the bail-in event, also the severity of the losses in case of bail-in. In both cases, this is non-sensitive bank data and regulators should ask to comply with these 
disclosure requirements.

The BRRD regulation has thus prompted renewed calls for making banks more transparent, following the line already furrowed by the Basel Committee (Basel Committee, 1998). The challenge of supervisors is to enhance market disclosure, while protecting financial institutions' proprietary information, with specific reference to bank risk-taking.

Particular attention should be paid to senior unsecured bonds, a "crucial" class of bonds for those who intend to invest in investment grade assets, as these show the greatest positive effect on yields and yield spreads after the introduction of the bail-in regulation.

\section{References}

Acharya, V. V., \& Ryan, S. G. (2016). Banks' financial reporting and financial system stability. Journal of Accounting Research, 54(2), 277-340. https://doi.org/10.1111/1475-679X.12114

Allen, F., Carletti, E., Goldstein, I., \& Leonello, A. (2015). Moral Hazard and Government Guarantees in the Banking Industry. Journal of Financial Regulation, 1, 30-50. https://doi.org/10.1093/jfr/fju003.

Ashbaugh-Skaifea, H., Collinsb, D. W., \& LaFond, R. (2006). The effects of corporate governance on firms'credit ratings. Journal of Accounting and Economics, 42, 203-243. https://doi.org/10.1016/j.jacceco.2006.02.003

Avgouleas, E., Goodhart, C., \& Schoenmaker, D. (2013). Bank Resolution Plans as a catalyst for global financial reform. Journal of Financial Stability, 9, 210-218. https://doi.org/10.1016/j.jfs.2011.12.002

Avgouleas, E., \& Goodhart, C. (2015). Critical Reflections on Bank Bail-ins. Journal of Financial Regulation, 1, 3-29. https://doi.org/10.1093/jfr/fju009

Balasubramnian, B., \& Cyree, K. B. (2011). Market Discipline of Banks: Why are Yield Spreads on Bank-Issued Subordinated Notes and Debentures Not Sensitive to Bank Risks. Journal of Banking \& Finance, 35, 21-35. https://doi.org/10.1016/j.jbankfin.2010.07.015

Basel Committee. (1998). Enhancing Bank Transparency: Public Disclosure and Supervisory Information That Promote Safety and Soundness in Banking Systems. September.

Berger, A. N., Himmelberg, C. P., Roman, R. A., \& Tsyplakov, S. (2018). Bank Bailouts, Bail-ins, or No Regulatory Intervention? A Dynamic Model and Empirical Tests of Optimal Regulation. FDIC, August $6^{\text {th }}, 1-69$. https://doi.org/10.2139/ssrn.3179226

Bhattacharya, S., Boot, A. W. A., \& Thakor, A.V. (1998). The Economics of Bank Regulation. Journal of Money, Credit and Banking, 30, 745-770.

Bradford, W., Chen, C., \& Zhao, Y. (2019). The effect of corporate governance on credit ratings: evidence from China's bond market. Journal of International Financial Management \& Accounting, 30(2), 113-144. https://doi.org/10.1111/jifm.12094.

Boccuzzi, G., \& De Lisa, R. (2017). Does Bail-in Definitely Rule out Bailout? Journal of Financial Management, Markets and Institutions, 1, 93-110. https://doi.org/10.12831/87061

Bushman, R. M. (2016). Transparency, accounting discretion and bank stability. Economic Policy Review, 129149.

Chari, V. V., \& Kehoe, P. J. (2016). Bailouts, Time Inconsistency and Optimal Regulation: A Macroeconomic View, American Economic Review, 106(9), 2458-2493. https://doi.org/10.1257/aer.20150157

Chennells, L., \& Wingfield, V. (2015). Bank failure and bail-in: an introduction, Bank of England Quarterly Bulletin, Q3, 228-241.

Conlon, T., \& Cotter, J. (2014). Anatomy of a Bail-in. Journal of Financial Stability, 15, 257-263. https://doi.org/10.1016/j.jfs.2014.04.001.

Covitz, D. M., Hancock, D., \& Kwast, M. L. (2004). A reconsideration of the risk sensitivity of US banking organization subordinated debt spreads: A sample selection approach. FRBNY Economic Policy Review, 7392.

Crespi, F., Giacomini, M., \& Mascia, D.V. (2019). Bail-In Rules and the Pricing of Italian Bank Bonds, European Financial Management, 25(5), 1321-1347. https://doi.org/10.1111/eufm.12206

Crespi, F., \& Mascia, D. V. (2018). The Bail-in effect: how the cost of funding through bonds has changed after the introduction of the BRRD. In: Crespi, F., Mascia, D.V. (Eds.), Bank Funding Strategies. Palgrave 
Macmillan Studies in Banking and Financial Institutions. Palgrave Macmillan, Cham. https://doi.org/10.1007/978-3-319-69413-9_4

Dam, L., \& Koetter, M. (2012). Bank bailouts and moral hazard: Evidence from Germany. Review of Financial Studies, 25(8), 2343-2380. https://doi.org/10.1093/rfs/hhs056

Da-Rocha-Lopes, S., Beck, T., \& Silva, A.F. (2018). Sharing the pain? Credit supply and real effects of bank bailins, EBA Staff Paper Series, 1, 1-62. https://doi.org/10.1093/rfs/hha067

Demirguc-Kunt, A., \& Huizinga, H. (1999). Market Discipline and Financial Safety Net Design, Policy Research working paper; World Bank Group, WPS 2183, Washington, D.C.

DeYoung, R., Gron, A., Torna, G., \& Winton, A. (2015). Risk overhang and loan portfolio decisions: small business loan supply before and during the financial crisis. The Journal of Finance, 70(6), 2451-2488. https://doi.org/10.1111/jofi.12356

Dewatripont, M. (2014). European banking: Bailout, bail-in and state aid control, International Journal of Industrial Organization, 34, 37-43. https://doi.org/10.1016/j.ijindorg.2014.03.003

Diamond, D. W., \& Verrecchia, R. E. (1991). Disclosure, liquidity, and the cost of capital. The Journal of Finance, 46(4), 1325-1359. https://doi.org/10.1111/j.1540-6261.1991.tb04620.x

Eliasson, E., Jansson, E., \& Jansson, T. (2014). The bail-in tool from a Swedish perspective. Sveriges Riksbank Economic Review, 2, 23-51.

Enoch, C., Stella, P., \& Khamis, M. (1997). Transparency and Ambiquity in Central Bank Safety Net Operations. International Monetary Fund, Working Paper, WP/97/138.

Enria, A. (2017). The 'banking reform package': CRD 5/ CRR 2/ BRRD 2, Treasury Standing Committee of the Senate of the Republic of Italy. Rome, 5 July, 1-9.

European Parliament and European Council, Directive 2014/59/EU.

European Parliament and European Council, Directive 2013/36/EU.

European Parliament and European Council, 806/2014/EU Regulation.

European Parliament and European Council, 575/2013/EU Regulation

Flannery, M. J., \& Sorescu, S. M. (1996). Evidence of Bank Market Discipline in Subordinated Debenture Yields: 1983-1991. Journal of Finance, 51, 1347-77. https://doi.org/10.1111/j.1540-6261.1996.tb04072.x

Francis, J. R., Khurana, I. K., \& Pereira, R. (2005). Disclosure incentives and effects on cost of capital around the world. The Accounting Review, 80(4), 1125-1162. https://doi.org/10.2308/accr.2005. 80.4.1125

Giuliana, R. (2019). Impact of bail-in on banks' bond yields and market discipline, May 25. http://dx.doi.org/10.2139/ssrn.2935259.

Gornicka, L. A., \& Zoican, M. A. (2016). Too international to fail? Supranational bank resolution and market discipline, Journal of Banking and Finance, 65, 41-58. https://doi.org/10.1016/j.jbankfin.2016.01.005

Granja, J. (2018). Disclosure Regulation in the Commercial Banking Industry: Lessons from the National Banking Era. Journal of Accounting Research, 56(1), 173-216. https://doi.org/10.1111/1475-679X.12193

Halaj, G., Huser, A. C., Kok, C., Perales, C., \& Van Der Kraaij, A. (2016). Systemic implications of the European bail-in tool: a multi-layered network analysis. Financial Stability Review, 120-129.

Huertas, T. F. (2013). The Case for Bail-ins. In Kenadjian, P. S. (Ed.), The Bank Recovery and Resolution Directive. De Gruyter, e-book.

Hüser, A. C., Hałaj, G., Kok, C., Perales, C., \& Van der Kraaij, A. (2017). The systemic implications of bail-in: a multi-layered network approach. Working Paper Series, European Central bank, No. 2010.

Jagtiani, J., Kaufman, G., \& Lemieux, C. (2002). The Effect of Credit Risk on Bank and Bank Holding Company Bond Yields: Evidence from the Post-FDICIA Period. Journal of Financial Research, 25, 559-575. https://doi.org/10.1111/1475-6803.00037

Klimek, P., Poledna, S., Farmer, J. D., \& Thurner, S. (2015). To bail-out or to bail-in? Answer from an agent-based model. Journal of Economic Dynamics and Control, 50, 144-154. https://doi.org/10.1016/j.jedc.2014.08.020

Lambert, R., Leuz, C., \& Verrecchia, R. E. (2007). Accounting information, disclosure, and the cost of capital. Journal of Accounting Research, 45(2), 385-420. https://doi.org/10.1111/j.1475-679X.2007.00238.x 
Laviola, S., Loiacono, G., \& Santella, P. (2015). The new EU banking resolution regime. Bancaria, 9, 46-62.

Leone, P., Porretta, P., \& Riccetti, L. (2019). European Significant Bank Stock Market Volatility: is there a Bail-in Effect? International Journal of Business and Management, 14(5), 32-51. https://doi.org/10.5539/ijbm.v14n5p32

Pablos, I. (2019). Has the New Bail-In Framework Increased the Yield Spread Between Subordinated and Senior Bonds? https://doi.org/10.2139/ssrn.3378073

Philippon, T., \& Salord, A. (2017). Bail-ins and Bank Resolution in Europe: A Progress Report, Geneva Reports on the World Economy Special Report 4. International Center for Monetary and Banking Studies (ICMB), Geneva (Switzerland).

Pigrum, C., Reininger, T., \& Stern, C. (2016). Bail-in: Who Invests in Noncovered Debt Securities Issued by Euro Area Banks? OesterreichischeNationalbank (OeNB). Financial Stability Report, 32, 101-119.

Schaefer, A., Schnabel, I., \& Weder di Mauro B. (2016). Bail-in Expectations for European Banks: Actions speak Louder than Words. Discussion Paper No. 11061, CEPR.

Sironi, A. (2003). Testing for Market Discipline in the European Banking Industry: Evidence from Subordinated Debt Issues. Journal of Money, Credit and Banking, 35, 443-472.

Wojcik, K. P. (2016). Bail-in in the Banking Union. Common Market Law Review, 53, 91-138.

Zhou, J., Rutledge, V., Bossu, W., Dobler, M., Jassaud, N., \& Moore, M. (2012). From bail-out to bail-in: mandatory debt restructuring of systemic financial institutions. IMF Staff Discussion Note, SDN/12/03.

\section{Notes}

Note 1 . The list of the banks included in the sample and the number of bonds issued by each of them is provided in the appendix - Table 6.

Note 2. As defined in Datastream, this yield would make the sum of the net present values of all assumed cash flows equal to the gross price of the bond.

Note 3. Datastream defines the maturity date as the date on which the unpaid principal balance of the bond becomes due and payable.

Note 4. This variable is defined as: ((10-TMAT)*REPO+TMAT*Risk-free $) / 10$ and RFREPO= RFREPO* $($ TMAT $<=10)+$ Risk-free* $($ TMAT $>10)$

Note 5. Results for the first level of bail-in hierarchy in 2016 are provided in the appendix in Table 5 - column IV. Secured bonds are not significantly associated with bond yields in 2016.

Note 6. All the findings of this work are confirmed by using ROA instead of ROE, and the ratio of non-performing loans over total gross loans as a bank risk measure throughout.

Note 7. In all the regressions the natural logarithm of banks' total assets is more significant than lagged logarithms from the previous year.

Note 8 . All the results are provided in the appendix - Table 5. 


\section{Appendix}

Table 5. Model specifications with bond yields to maturity as dependent variable and "bail-in severity" or "bail-in hierarchy" as independent variables

\begin{tabular}{|c|c|c|c|c|c|c|}
\hline $\mathbf{Y M}$ & $\begin{array}{c}\text { I } \\
\text { Monthly }\end{array}$ & $\begin{array}{c}\text { II } \\
(2014-2016)\end{array}$ & $\begin{array}{c}\text { III } \\
(2014-2016)\end{array}$ & IV (2016) & $\begin{array}{c}\mathrm{V} \\
\text { Year FE }\end{array}$ & $\begin{array}{c}\text { VI } \\
\text { Year \& } \\
\text { Country FE }\end{array}$ \\
\hline BLNB & $\begin{array}{c}0.3890 * * * \\
(0.0167)\end{array}$ & & & & & \\
\hline BAIL SEV & & $\begin{array}{c}0.0577 * * * \\
(0.0058)\end{array}$ & & & $\begin{array}{l}0.0216^{*} \\
(0.0115)\end{array}$ & \\
\hline BAILHIER=1 & & & & $\begin{array}{c}-.0144 \\
(0.0336)\end{array}$ & & \\
\hline BAILHIER=2 & & & $\begin{array}{c}0.0644 * * * \\
(0.0181)\end{array}$ & & & $\begin{array}{c}0.2156 * * * \\
(0.0296)\end{array}$ \\
\hline BAILHIER=3 & & & $\begin{array}{c}-.1172 * * * \\
(0.0428)\end{array}$ & & & \\
\hline TMAT & $\begin{array}{c}0.0078^{* * *} \\
(0.0008)\end{array}$ & $\begin{array}{c}0.0110^{* * * *} \\
(0.0029)\end{array}$ & $\begin{array}{c}0.0098 * * * \\
(0.0026)\end{array}$ & $\begin{array}{c}-.0070 \\
(0.0084)\end{array}$ & $\begin{array}{c}0.0234 * * * \\
(0.0075)\end{array}$ & $\begin{array}{c}0.0258^{* * * *} \\
(0.0056)\end{array}$ \\
\hline AMOUNT & $\begin{array}{c}-.0243 * * * \\
(0.0040)\end{array}$ & $\begin{array}{c}-.0040 \\
(0.0048)\end{array}$ & $\begin{array}{c}0.0005 \\
(0.0044)\end{array}$ & $\begin{array}{c}0.0065 \\
(0.0079)\end{array}$ & $\begin{array}{c}-.0626^{* * *} \\
(0.0091)\end{array}$ & $\begin{array}{c}-.0571 * * * \\
(0.0078)\end{array}$ \\
\hline $\mathrm{CP}$ & $\begin{array}{c}0.2393^{* * * *} \\
(0.0044)\end{array}$ & $\begin{array}{c}-.1236^{* * *} \\
(0.0055)\end{array}$ & $\begin{array}{c}-.1205^{* * *} \\
(0.0052)\end{array}$ & $\begin{array}{c}-.1136^{* * *} \\
(0.0092)\end{array}$ & $\begin{array}{c}0.0705^{* * *} \\
(0.0099)\end{array}$ & $\begin{array}{c}0.0886^{* * * *} \\
(0.0082)\end{array}$ \\
\hline $\operatorname{ROE}(\mathrm{t}-1)$ & & $0.0007(0.0007)$ & $\begin{array}{c}0.0018^{* * *} \\
(0.0006)\end{array}$ & $\begin{array}{c}-.0151 * * * \\
(0.0023)\end{array}$ & $\begin{array}{c}-.0163 * * * \\
(0.0013)\end{array}$ & $\begin{array}{c}-.0062 * * * \\
(0.0007)\end{array}$ \\
\hline BSIZE & & $\begin{array}{c}-.0825 * * * \\
(0.0120)\end{array}$ & $\begin{array}{c}-.0256 * * * \\
(0.0093)\end{array}$ & $-.0149(0.0160)$ & $\begin{array}{l}-.0476^{* *} \\
(0.0228)\end{array}$ & $\begin{array}{c}-.0532 * * * \\
(0.0172)\end{array}$ \\
\hline PIIGS & & $\begin{array}{c}-.2451 * * * \\
(0.0265)\end{array}$ & $\begin{array}{c}-.2167 * * * \\
(0.0254)\end{array}$ & $\begin{array}{c}-.1151 * * * \\
(0.0438)\end{array}$ & $\begin{array}{c}0.8834 * * * \\
(0.0468)\end{array}$ & \\
\hline RF-REPO & & $\begin{array}{c}--1.1387^{* * *} \\
(0.0343)\end{array}$ & $\begin{array}{c}-1.0122 * * * \\
(0.0306)\end{array}$ & $\begin{array}{c}-1.6374 * * * \\
(0.2178)\end{array}$ & $\begin{array}{l}0.2337^{*} \\
(0.1303)\end{array}$ & $\begin{array}{c}0.2814^{* * *} \\
(0.0989)\end{array}$ \\
\hline $\begin{array}{l}\text { YM } \\
(\mathrm{t}-1)\end{array}$ & $\begin{array}{c}0.4687 * * * \\
(0.0018)\end{array}$ & $\begin{array}{c}1.2630^{* * *} \\
(0.0068)\end{array}$ & $\begin{array}{c}1.2357^{* * *} \\
(0.0067)\end{array}$ & $\begin{array}{c}1.4081^{* * *} \\
(0.0107)\end{array}$ & $\begin{array}{c}0.4742 * * * \\
(0.0083)\end{array}$ & $\begin{array}{c}0.5112 * * * \\
(0.0073)\end{array}$ \\
\hline Intercept & $\begin{array}{c}0.6067 * * * \\
(0.0754)\end{array}$ & $\begin{array}{c}-4.2507 * * * \\
(0.4808)\end{array}$ & $\begin{array}{c}0.2797 * * \\
(0.1171)\end{array}$ & $\begin{array}{c}0.2867 \\
(0.2089)\end{array}$ & $\begin{array}{c}-.0668 \\
(0.9558)\end{array}$ & $\begin{array}{c}1.5005^{* * *} \\
(0.2336)\end{array}$ \\
\hline Cross sections & 6984 & 4656 & 4855 & 4778 & 4656 & 4855 \\
\hline Tot. Obs. & 285840 & 9610 & 11057 & 4778 & 11958 & 15095 \\
\hline R-squared & 0.2160 & 0.8298 & 0.8284 & 0.8290 & 0.4339 & 0.4953 \\
\hline Adjusted R-squared & 0.2160 & 0.8296 & 0.8282 & 0.8286 & 0.4331 & 0.4944 \\
\hline Durbin Watson & 2.1666 & 0.9618 & 1.0016 & & 2.0200 & 1.7068 \\
\hline
\end{tabular}

Note. This table reports the regression results using pooled ordinary-least-squares between bond yields and "bailinable" status in the first column, "bail-in severity" in columns II and V, the first level of "bail-in hierarchy" in Column IV, the second and third levels of the hierarchy in columns III and the second level of the hierarchy in the last column. The first column presents the regression results for monthly bond yields, column II and III the results over the period 2014-2016 and column IV the results for the first level of bail-in hierarchy in 2016. Columns V reports the results with year fixed effects: all specifications include year fixed effects (not shown) and column VI with year and country fixed effects: all specifications include year and country fixed effects (not shown). The dependent variable is bond yields to maturity (YM). The explanation variables are: "bailinable" status dummy variable (BLNB), "bail-in hierarchy" (BAIL HIER), "bail-in severity" (BAIL SEV), bond time to maturity (TMAT), bond issued amount (AMOUNT), bond coupons (CP), bank return on equity (ROE), bank size (BSIZE), PIIGS dummy variable (PIIGS) and the weighted average of risk-free (EURIRS) and REPO (RF-REPO). All regressions are estimated with robust standard errors that are reported in parentheses. ${ }^{* *},{ }^{* *}, *$ indicate statistical significance at $1 \%, 5 \%$ and $10 \%$, respectively. The number of observations varies due to data availability. 
Table 6. Sample - List of the 45 significant supervised European banks included in the sample and the number of bonds issued by each of them

\begin{tabular}{|c|c|c|c|c|}
\hline & Bank name & $\begin{array}{l}\text { Bonds } \\
\text { issued }\end{array}$ & Country & $\begin{array}{l}\text { Bank size } \\
\text { (total assets } € \text { ) }\end{array}$ \\
\hline 1 & AAREAL BANK AG & 120 & Germany & $50-75$ bn \\
\hline 2 & ABN AMRO BANK NV & 27 & The Netherlands & $300-500$ bn \\
\hline 3 & BANKIA SA & 14 & Spain & $150-300 \mathrm{bn}$ \\
\hline 4 & BAYERISCHE LANDESBANK & 501 & Germany & $150-300 \mathrm{bn}$ \\
\hline 5 & BANKINTER SA & 12 & Spain & $50-75$ bn \\
\hline 6 & BANCO BILBAO VIZCAYA ARGENTARIA SA & 31 & Spain & $500-1,000$ bn \\
\hline 7 & BANCO BPI SA & 8 & Portugal & $30-50 \mathrm{bn}$ \\
\hline 8 & BANCO COMERCIAL PORTUGUES SA & 15 & Portugal & $75-100 \mathrm{bn}$ \\
\hline 9 & BANCO MARE NOSTRUM SA & 4 & Spain & $30-50 \mathrm{bn}$ \\
\hline 10 & BANCO POPULAR ESPANOL SA & 25 & Spain & $150-300$ bn \\
\hline 11 & BANCO DE SABADELL SA & 24 & Spain & $150-300 \mathrm{bn}$ \\
\hline 12 & BANCO SANTANDER SA & 15 & Spain & $>1,000$ bn \\
\hline 13 & BNP PARIBAS SA & 11 & France & $>1,000$ bn \\
\hline 14 & BANCA POPOLARE DI SONDRIO SCA & 20 & Italy & $30-50$ bn \\
\hline 15 & BANCA POPOLARE DI VICENZA SPA & 47 & Italy & $30-50$ bn \\
\hline 16 & BPCE SA & 66 & France & $500-1,000$ bn \\
\hline 17 & BPER BANCA SPA & 17 & Italy & $50-75$ bn \\
\hline 18 & BANCO BPM SPA & 73 & Italy & $125-300$ bn \\
\hline 19 & BANQUE FEDERATIVE DU CREDIT MUTUEL & 19 & France & $300-500$ bn \\
\hline 20 & CAIXA BANK SA & 49 & Spain & $300-500 \mathrm{bn}$ \\
\hline 21 & BANCA CARIGE SPA & 27 & Italy & $30-50$ bn \\
\hline 22 & COMMERZBANK AG & 141 & Germany & $500-1,000$ bn \\
\hline 23 & CREDIT AGRICOLE SA & 55 & France & $>1,000$ bn \\
\hline 24 & CREDITO EMILIANO HOLDING SPA & 8 & Italy & $30-50$ bn \\
\hline 25 & DEUTSCHE BANK AG & 183 & Germany & $>1,000$ bn \\
\hline 26 & DEUTSCHE PFANDBRIEFBANK AG & 121 & Germany & $50-75$ bn \\
\hline 27 & $\begin{array}{l}\text { DZ BANK AG DEUTSCHE ZENTRAL- } \\
\text { GENOSSENSCHAFTSBANK }\end{array}$ & 516 & Germany & $300-500$ bn \\
\hline 28 & ERSTE GROUP BANK AG & 445 & Austria & $150-300 \mathrm{bn}$ \\
\hline 29 & EUROBANK ERGASIAS SA & 2 & Greece & $50-75$ bn \\
\hline 30 & HSH NORDBANK AG & 554 & Germany & $75-100 \mathrm{bn}$ \\
\hline 31 & INTESA SAN PAOLO SPA & 73 & Italy & $500-1,000 \mathrm{bn}$ \\
\hline 32 & LANDESBANK BADEN-WURTTEMBERG & 602 & Germany & $150-300$ bn \\
\hline 33 & $\begin{array}{ll}\text { LANDESBANK } & \text { HESSEN-THURINGEN } \\
\text { GIROZENTRALE } & \end{array}$ & 573 & Germany & $150-300$ bn \\
\hline 34 & $\begin{array}{l}\text { LANDESKREDITBANK } \\
\text { WURTTEMBERG-FORDERBANK }\end{array}$ & 18 & Germany & $50-75$ bn \\
\hline 35 & LIBERBANK SA & 2 & Spain & $30-50 \mathrm{bn}$ \\
\hline 36 & MEDIOBANCA SPA & 27 & Italy & $50-75$ bn \\
\hline 37 & BANCA MONTE DEI PASCHI DI SIENA SPA & 55 & Italy & $150-300 \mathrm{bn}$ \\
\hline 38 & MUNCHENER HYPOTHEKENBANK EG & 144 & Germany & $30-50 \mathrm{bn}$ \\
\hline 39 & OP YRITYSPANKKI OYJ & 6 & Finland & $50-75$ bn \\
\hline
\end{tabular}




\begin{tabular}{lllll}
\hline 40 & COOPERATIVE RABOBANK UA & 22 & The Netherlands & $500-1,000 \mathrm{bn}$ \\
41 & SLOVENSKA SPORITEL'NA AS & 4 & Slovakia & $10-30 \mathrm{bn}$ \\
42 & SOCIETE GENERALE SA & 15 & France & $>1,000 \mathrm{bn}$ \\
43 & UNIONE DI BANCHE ITALIANE SPA & 97 & Italy & $100-125 \mathrm{bn}$ \\
44 & UNICREDIT SPA & 59 & Italy & $500-1,000 \mathrm{bn}$ \\
45 & VENETO BANCA SPA & 8 & Italy & $30-50 \mathrm{bn}$ \\
Total & & 4855 & & \\
\hline
\end{tabular}

\section{Copyrights}

Copyright for this article is retained by the author(s), with first publication rights granted to the journal.

This is an open-access article distributed under the terms and conditions of the Creative Commons Attribution license (http://creativecommons.org/licenses/by/4.0/). 